\title{
Peste, guerre et idéologie sans frontières
}

Stephen Leeder

Editor-in-Chief

mja@mja.com.au

doi: 10.5694/mjal4.c1215
These horrors ... [were] not caused by the ordinary negative human sentiments, as Spinoza called them - fear, greed, tribal hatreds, jealousy, love of power - though of course these have played their wicked part. They have been caused, in our time, by ideas; or rather, by one particular idea ... There are men who will kill and maim with a tranquil conscience under the influence of the words and writings of those who are certain that they know perfection can be reached.

- Isaiah Berlin (1909-1997), British philosopher, political theorist, scholar and historian of ideas, receiving in 1994 an honorary Doctor of Laws at the University of Toronto. ${ }^{1}$

he moat of the Tower of London was transformed on 5 August this year, the centenary of the first day of Britain's involvement in World War I. An installation of red ceramic poppies (see our cover) called Blood swept lands and seas of red - a line from a war poem by an unknown soldier created by artists Paul Cummins and Tom Piper filled the space. One red poppy, about $10 \mathrm{~cm}$ in diameter, commemorated one British or colonial military life lost. It cost about $£ 1$ million to create, pack and transport. By 11 November, 888246 poppies populated the moat and millions of people had visited it. The Last Post marked each sunset over the installation until it closed on Armistice Day. It has now been removed and the poppies sold to the public. The expected proceeds of more than $£ 15$ million will be shared among several service charities. ${ }^{2}$

After World War I came influenza. What colour, what flower, would we choose to represent the tens of millions who died? A war fought over borders had given way to a plague that had no respect at all for borders, hitching a ride with troops returning home from the Western Front regardless of where they lived.

A century later, a conflation of wars, driven by ideologies, and plague are evident again. The fluctuating loyalties of tribal and religious groups across the Levant and into Iraq puzzle and confuse us. Where do the people belong? The Islamic State, with its televised beheadings and atrocities against

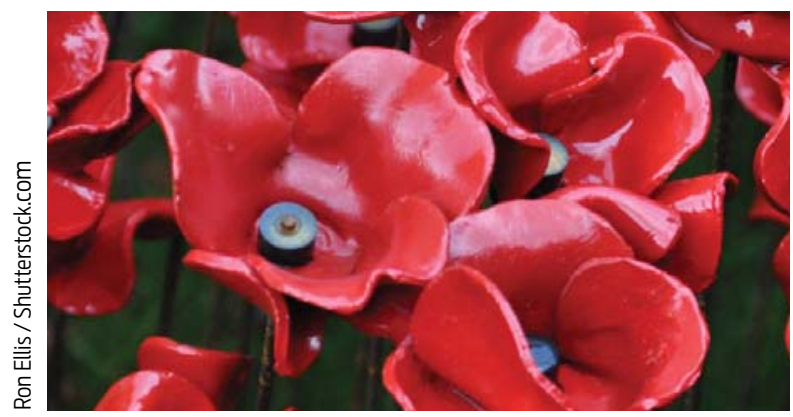

whole populations, leaves us outraged. And what of the Ukraine, where borders that were not properly constructed after World War II provoke fresh battles and human suffering?

And now Ebola surges in the ghettos and povertyracked villages and towns of West Africa. Primitive hospitals in Sierra Leone closed within weeks of Ebola commencing its epidemic march. Relatives hugged their dying children in helpless, benighted pacts of death.

Yet somewhere above this mayhem, medicine, at its best, recognises and manages plagues, copes with wars, is unpersuaded by the clamour of ideology, and knows no borders as it gets on with its job. Médecins Sans Frontières is in Africa and in many other troubled and needy places, and we salute its courage and professionalism. Others are there, too.

And so in the face of Ebola, among two million or more refugees in camps of Lebanon and Turkey, in Gaza and in Israel, even in parts of Syria, you will find doctors and nurses, often supported by volunteers, doing their best, giving their energy and skill and sometimes their lives to those who suffer.

\section{The century that was}

This year the Medical Journal of Australia turned 100. This has been a complex hundred years for humanity, with indisputably brilliant advances in technology, increasing global democracy, massive improvements in global health and infant mortality, and huge reductions in poverty. But it has also, as noted, been a century of fearful wars, of appalling plagues such as HIV, and hugely destructive rampant ideologies. The MJA has seen a lot of this action, recording events and developments from a medical perspective. It has sought to distil wisdom from the science, the clinical practice and the observation of the Australian medical profession.

So we could imagine our own floral tribute commemorating men and women who have contributed to Australian medicine. Sacrifice, courage and love are expressed in wonderfully varied forms. In war and peace, when pestilence sleeps and when it rages, when once solid borders fall, the central values of medicine remain steadfast. As a human enterprise, collectively and individually, doctors lose the plot occasionally and we then must seek our own recovery. But generally medicine stands solid, not bound by borders, imprisoned by ideology, fractured by fundamentalism or paralysed by plagues. Médecins Sans Frontières symbolises us at our best.

So permit yourself a small slice of pride alongside your (modest) serve of pudding this Christmas as you reflect on the past 100 years! 